\title{
Assessment of Socioeconomic Factors and Stakeholders Involved in Dzanga Sangha Complex Protected Area, Central African Republic
}

\author{
Ngbo-Ngbangbo Louis Maxime \\ School of Environmental Studies, China University of Geosciences, 388 Lumo Road, 430074, Wuhan, China \\ Tel: 86-27-6788-5999 E-mail:ngbo2@yahoo.fr \\ Ge Jiwen (Corresponding author) \\ School of Environmental Studies, China University of Geosciences, 388 Lumo Road, 430074, Wuhan, P.R.China \\ Tel: 86-27-6249-3959 E-mail: gejiwen2002@yahoo.com.cn \\ Nahayo Alphonse
}

School of Environmental Studies, China University of Geosciences, 388 Lumo Road, 430074, Wuhan, China

Tel: 86-27-5983-9745Ｅ-mail: nahayalfa@gmail.com

\begin{abstract}
Dzanga Ndoki is the main National Park located in Dzanga Sangha Complex Protected Area, Central African Republic. This study assesses socioeconomic factors and different NGOs involved in management of the park. A questionnaire survey was used to collect data in 8 villages around the park. Results on socioeconomic study showed that younger people aged of 20-25 (36.55\%) and between 25-30 (27. 81\%) are more dynamic in the forest than elderly ones (age >35) who represented (5.61\%). Better education may help in conservation of the Dzanga Ndoki due to different employment. Admittedly, $39.27 \%$ of people had primary education, $(6.4 \%)$ had secondary level, $(1.33 \%)$ had higher education and $53.18 \%$ were illiterate. Employment and access to market are missing. Participative management has mostly focused on villages of Mossapoula and Yandoumbe. Ba Aka people $(60.52 \%)$ were not satisfied with the project. In addition, poor conditions of local people let them very dependent to forest resources (illegal hunting and gathering). This project is however unable to provide financial support to national NGOs and associations for local people.
\end{abstract}

Keywords: Socioeconomic factors, Participative Management, Stakeholders, Questionnaire Survey, Dzanga Ndoki National Park, Dzanga Sangha Complex Protected Area, Central African Republic

\section{Introduction}

Protected areas have deep historical roots: they have existed in varied forms in diverse ancient cultures, dating back to early pre-agrarian societies in Asia and The Near East (Allin 1990, Runte 1997). Chinese and South American civilizations from 3000 year before present have recorded decrees setting a side land to plants and animals (Stenling, 2002). Sacred forest groves that prohibited all forms of extractive use represent an early manifestation of protected area (Chandrashekara and Sankar, 1998). Royalty created reserves, such as land set aside for game hunting, to exclude commoners. The unparalleled scale of ecological change stemming from the rise of colonialism and European expansion spurred conservation action and protected area establishment. The establishment of the first National park in the United States, such as Yosemite and Yellowstone, stemmed from a philosophy that valued these areas as grand monuments (Runte, 1997). Protected area form the cornerstone of biodiversity conservation efforts worldwide (Margules and Pressey, 2000). A global system of protected area currently protects close to 105000 sites over approximately 20 million $\mathrm{km}^{2}$, covering about 12.2 percent of planet's land area (Chape et al., 2005).

Protected area has been defined by the World Conservation Union (IUCN) "as an area of land and sea especially dedicated to the protection and maintenance of biological diversity, natural and associated cultural resources, and managed through legal or other effective means" (IUCN, 1994). While other definitions may have been adopted by individual states or organizations, the World Conservation Union is widely accepted. Protected Area also knows as Parks or Reserves have been established at international, regional, state, municipal scale and many are linked as networks or system.

The political context of biodiversity conservation in Central African Republic begins with the Ministry of Waters, Forests, Hunting, Fishing, and Environment, which is charge with the responsibility for natural ecosystem protection (Ngatoua, 1993). Two action zones are delineating within the country, the first concern: hunting and natural history zones and the second deals with buffer zones. The former includes hunting and conservation activities but the latter contains agro-pastoral and industrial activities. Protected areas in Central African Republic divided into three categories: forbidden access reserves, no hunting national parks, and wildlife reserve, which allow customary rights. A community NGO is integrates into the revenue sharing and decision-making processes. Project management staff acts as partners in biodiversity management.

More recently, CAR has pioneered the creation of a new category of protected area in the annals of the conservation of Central African nature. I refer to the Dzanga-Sangha Special Dense Forest Reserve, created in 1990. Diverse economic activities have been practiced in the course of this multiple-use reserve's history, notably 
forest exploitation, agriculture, and hunting. We have facilitated the growth of a local non-governmental organization, the Committee for Development of Bayanga (CDB), to be involved in decision-making about revenue uses within reserve resident communities. That, in brief, has been our principal approach to the issue. Our interior regulations are such that $90 \%$ of tourism revenues remain in the Reserve ( $40 \%$ to local communities channeled through the $\mathrm{CDB}, 50 \%$ to reserve administration for upkeep and infrastructure maintenance). Ten percent of revenues, a very modest sum relative to other African precedents for protected areas leave the region and goes to the national level. With the creation of the Dzanga-Sangha Special Dense Forest Reserve and the Dzanga-Ndoki National Park, the Central African Republic now has a network of 16 protected areas, and the total surface area now protected is $76,610 \mathrm{~km}^{2}$ (Ngatoua, 1993). This increase is testimony to the will of the Central African Republic to preserve more natural ecosystems for the needs of present and future generations. In fact, by creating the Dzanga-Sangha Special Reserve, the Central African Republic has opted for a new conservation strategy, one of integrated conservation and development.

Since 1990, in Central Africa countries, there are programs to demonstrate the possibility of more effective management of protected areas according to participatory approaches. (Ndinga, 1988) This strategy is based on the following main reasons:

The Conservation of the Dzanga Sangha in Central African Republic with its full array of species, viable populations, and ecosystems would depend on the effective management, which offers many opportunities to local people to have better living conditions. However, many factors like poverty among local population, lack of food and income generating activities, land scarcity; immigrant people, poaching activities and the creation of new village around protected area, constitute the major threats for Dzanga Sangha specially Dzanga-Ndoki National Park management. In addition, NGOs do not take in consideration all people, the reason why there is a social conflict between local people and conservationists. This situation needs an urgent correction in order to carry out a better way for management approach for long-term conservation of Dzanga Ndoki national park that also would govern Dzanga Sangha project.

The objectives and aims of this study are the following:

The overall objective aims at assessing the socioeconomic factors and the involvement of stakeholders in Dzanga-Ndoki National Park management.

The specific objectives are as follows:

Assessing the participative management integrated in Dzanga-Ndoki National Park;

Evaluating the perception of minority people called "Ba Aka" toward Dzanga Sangha Special Reserve;

Assessing socioeconomic factors prevailing behind Dzanga Ndoki National Park management.

Our study will be focused on Dzanga Sangha, which is one of those protected areas where the participative management had been initiated since 1990. On the completion of this study, the following hypotheses will have been verified:

Due to the lack of consultation and implementation of local and pygmies' people (minority people) in decision making of the Dzanga Sangha forest management (Nelson, 2008), results are still not good in terms of participation of people concerned.

The statuses of living conditions to local and pygmies' people constitute a major problem to the success of Dzanga Ndoki management. It is essential that those conservationist who carry out conservation and economic development Programs and direct environmental policies in Central Africa Republic to have the tools necessary for assessing and analyzing biological diversity and the interactions between human and wildlife (e.g. Saterson, 1990; Cracraft, 1995). The abilities of expatriate scientists to provide additional expertise for research development, and conservation projects are limited because they are not familiar with the reality of the place. To further complicate capacity-building efforts, research and educational institutions within Central Africa have been challenged by tumultuous political and economic transitions in recent years. As there is a gap among local researchers to invest more their time in conservation issues, this study would be an attempt to correct this mistake. In addition, as local and pygmies people have always been neglected in terms of effective participation in Dzanga Sangha management. This study will elucidate how this attitude of NGOs in charge of conservation has led to failure and how useful would be if people were consulted in order to contribute to the decision making of Dzanga Sangha management.

\section{Material and methods}

Data have been collected in July 2009 by using the questionnaire survey administered in 8 villages around Dzanga Ndoki National Park. Microsoft Excel was used to calculate some percentages. SPSS (Statistical package for Social Science 13.0) was used for data entry and analysis. Cross tabulation and chi-square test of independence were used to determine the perceptions of groups of people towards different variables (George et al. 2006). In total 6468 people grouped in 1560 households were registered in these villages. Then, 180 households were randomly selected to serve as respondents to the questionnaire. This is to say, 180 respondents were interviewed and one representative for each household was randomly selected. The respondents were asked 
only to say how they participate in the local decision process, how they would like to become more active in the decision making process, how they comply with the law and why and where the NGOs invest more their activities. They respondents were also asked about their daily activity, the product they collect in the forest and the time spent. Data on the socioeconomic factors were collected as well.

\section{Study area}

The Dzanga Sangha Complex Protected Area (DSCPA) is located at the extreme Southwest of Central African Republic. On plateaus broken up by alluvial plains between latitude $02^{\circ} 13^{\prime} 26^{\prime \prime}$ to $3^{\circ} 24^{\prime} 37^{\prime \prime}$ North and longitudes $15^{\circ} 41^{\prime} 20^{\prime \prime}$ to $16^{\circ} 37^{\prime} 20^{\prime \prime}$ East, with an altitude that reaches nearby $700 \mathrm{~m}$ and comprising a dense forest block of $\left(4589 \mathrm{~km}^{2}\right)$. The Sangha is adjacent to the Nouabale Ndoki National park of Congo and the Lobeke National park of Cameroon, which together form a trinational conservation zone (Bokoto, 2004).

The Dzanga Sangha complex is a composite of several areas; each having a status defining its relevant category. It includes the Dzanga Ndoki National Park composed of 2 sectors, Dzanga $\left(495 \mathrm{~km}^{2}\right)$ and Ndoki $\left(725 \mathrm{~km}^{2}\right)$, and the Dzanga Sangha $\left(3359 \mathrm{~km}^{2}\right.$ ), a multiple zone in which human activity is controlled. The two sectors of the Dzanga Ndoki National Park meet the traditional criteria of classification: all fishing, gathering, hunting, mineral and forest exploitation activities are prohibited. The Special Reserve contains 8 villages including Bayanga, the administrative center. The Special Reserve is internal such that no new village can be created. The Special Reserve Dzanga Sangha and Dzanga Ndoki National park represent the cultural, faunal and floristic wealth of the most beautiful region in Central African Republic. This zone possesses vegetation dominated by semi deciduous, evergreen, swampy and flooded forest: (21 Eurphobiacae family, 16 Rubiaceae , 14 Annonnnaceae, 13 Caealpuniaceae 11 Sterculiaceae , 10 Ebenaceae ) but also contain the mono dominant forests of savannah toward the villages, and forest exploitation roads. These varied ecosystems provide a habitat for 105 species of land mammals identified (Blom, 2001) in particular: the forest elephant Loxodonta africana cyclotis, sixteen species of primates, among them the Gorilla gorilla gorilla, the chimpanzee Pan troglodytes and at least six small nocturnal; fourteen species of ungulates, including the bongo antelope Tragelaphus euryceros, fourteen species of carnivores, including the leopard Panthera pardus and spotted neck otter Lutra maculicollis. The Hippopotamus amphibious still have a significant population along the Sangha River. The avifauna (birds) includes 379 species with a new species of Turdidae, Stiphrornis saghae, was described in 1999 and had not been found elsewhere (Mike, 2004). (Figure1), (Table 1)

\section{Results and discussion}

In Central African Republic, the forest resources offer many services to people. People in Dzanga Sangha region are now facing many changes in their daily life after the restriction on forest resources exploitation, new method called "participative management" had been introduced in all villages. Then, results of socioeconomic factors and the effectiveness of Dzanga Sangha management are not sufficient according to the poverty, which is still prevailing in the villages around Dzanga Ndoki.

\subsection{People and gender (according to Special reserve Dzanga Sangha population)}

In these eight villages, people recorded were 6468 of which 3507 were female $(54.22 \%)$. The male were 2961 $(45.77 \%)$. Bayanga population had 3925, with 2175 female $(55.41 \%), 1750$ male that represented $44.58 \%$. Mossapoula had 598 whose 307 (51.33\%) were female, 291 male (48.66\%). The two last villages less inhabited are Yondo with 131 people whose 70 were female $(53.43 \%), 61$ were male $(46.56 \%)$. Finally, Yobe is inhabited by 25 people of which $14(56 \%)$ are female whereas only 11 people are male $(44 \%)$.

As we can see from this chart, female people are larger than male in all villages. This result is not new that is the same result of census 2003 (on http//www.humain tariana appeal.net) in Central African Republic in general. (Figure2)

\subsection{Households}

\subsubsection{Households (according to all population)}

Dzanga Sangha Special Reserve had 1560 households with 6468 people. First, Bayanga had 990 households with 3925 people. Afterwards Mossapoula had 128 households where live 598 people. Furthermore, Bomandjokou had 108 households with 531 people. Finally, Yondo had 32 households with 131 people and Yobe had 7 households with 25 people.

Here we saw that village which had many households had many people. Bayanga had the highest household because of migration. Immigrant communities outnumber the local population that represented more than half of the total population (Mogba et al., 1996). (Figure 3)

4.2.2 Household size (according to our sample)

Bayanga village, with 120 households, has 720 people. Yandoumbe is the second with 40 people grouped in to 8 households. The last is Yobe with 2 households sheltering 8 people. In total, 1075 people were recorded into 180 households with an average of 6 individuals in each family.

The household size has positive relationship with forest resources exploitation. A household with a higher size 
needs more resources or must work hard to meet family needs. If this household with large family does not have a good job with a higher salary, it will be obliged to extract more forest resources: by poaching, gathering (Arnold and Bird, 1999). As a result Bomandjoukou have a highest number of households followed by Babongo, Mossapoula, Bayanga, (Yandoumbe and Lidjombo), then (Yondo and Yobe). (Figure 4)

\subsubsection{Age of Households}

The total number of household's was 1075, Young people aged of 20-25 were many: 393 (36.55\%) followed by those aged "between" 25-30: 299 (27.81\%). The least represented were elderly people (>35): 61 (5.61\%).

Many people were young in these villages. Young households were able to get more resources from the forest than old one. Their needs were different from old households because they needed to create their own family, so they must extract more resources to build house, to sell and earn lot of money to get good conditions of living. Very young people disliked to extract forest resources even tough they had enough energy to do so. They consider forest products collection like old-fashion. Old men are usually busy, tired and do not have enough strength for forest labor (climbing palm tree for raffia palm wine, hunting). National Park Dzanga Ndoki threatened because of the young population who live in the Special Reserve. (Figure 5)

\subsection{Education level}

4.3.1 Education (according to primary, secondary and tertiary schools)

People with primary education were $2540(39.27 \%)$ but only $418(6.46 \%)$ had secondary education. We have noticed that only 70 people have graduated from higher education $(1.08 \%)$, others people which represented $53.18 \%$ were illiterate or without any form of education. According to the number of people in each village, Bayanga people were 3925. Only 1970 went to school (50.19\%). Yandoumbe had 261 with 154 literate (59\%). Mossapoula had a total number of 598 with 308 literate that represented $51.50 \%$. Total people in Yondo were 131 , with $50(38.16 \%)$ literate. Yobe has 25 , with $10(40 \%)$ literate. To compare theses villages the first one is Yandoumbe, followed by Mossapoula, Bayanga, Lidjombo, Babongo, Yondo, Yobe and Bomadjokou. Towards the secondary school and tertiary school, Bayanga is the first which had $400(10.19 \%)$ for secondary and 70 $(1.08 \%)$ for tertiary school. The second was Yandoumbe with $4(1.53 \%)$ for secondary, followed by Mossapoula with $8(1.33 \%)$ for secondary school, the fourth was Lidjombo with $3(0.54 \%)$ secondary school, Babongo had 2 $(0.44 \%)$, Bomandjokou had $1(0.18 \%)$, Yondo and Yobe both had gotten $(0 \%)$ in secondary school. The average of education was $46.81 \%$. The range of secondary school was $(1.08 \%)$.

According to our study, there is lack of education in general because more people in these villages were illiterate. Particularly, the rate of secondary school was very low $(1.08 \%)$ because there is no secondary school in the 8 villages around Dzanga Ndoki National Park even Bayanga which is the sub prefecture of Nana Mbaere Region. People in these villages were poor and could not send their kids to the nearest city like Berbarity, Nola, Bossangoa to continue their studies. They needed a lot of money to rent houses, pay for food, medicine, books and notebooks. Tertiary schools are also absent even tough it is free. People who graduated from primary school had limited economic means to meet their daily needs, as the level of education is not enough to support their families. In contrast, those who went beyond primary education had a wider range of opportunities to get money like commercial activities, teaching or working in the government agencies. The reason why they do not rely on forest product undoubtedly, illiterate people are those who often enter the forest to collect food. (Figure 6)

4.3.2 Gender (primary school)

Among 2540, people graduated from primary school. Men were 1559 amounting to (61\%), the female were 981, which is $(38.62 \%)$. In Bayanga with 1500, male were $906(60.4 \%)$. Female were $594(39.6 \%)$. The last is Yondo with 50 primary school graduates of which 38 are male $(76 \%)$ and 12 female $(24 \%)$. We can see that female education is lower than male's in all villages. (Figure7)

4.3.3 Gender (secondary school)

418 people had a secondary level of education then, $312(74.64 \%)$ are male and $105(25.11 \%)$ are female. Bayanga had 400, male were 300 (75\%) with 100 female (25\%). Followed by Mossapoula with 8 people, male were $5(62.5 \%)$ and $3(37.5 \%)$. Yondo and Yobe which are the last 2 villages with lower people had got $(00 \%)$. (Figure 8)

\subsubsection{Gender (tertiary school)}

70 people attended higher education of which 55 are male (78.57\%) and 15 female (21.42\%).

The fact that women are often dealing with different domestic activities like cooking, washing clothes and taking care of children; the reason why their education is still slow. In addition, women also got precociously pregnant. (Figure 9)

\subsection{Health services and principal diseases}

Malaria, Diarrhea, cough and intestinal parasites were principal diseases, the causes of these diseases are related to water shortage. The region has a big forest where mosquitoes were often present during the raining season. Diarrhea and intestinal parasites were often the result of some bad food or lack of drinking water in the area. In 
addition, there was only one hospital in the region.

Currently, many peoples in the Special Reserve depend on traditional heath services (traditional medicine). Local people and pygmies' people employ 20,000 plant species for medicines in Central Africa (Melchias, 2001). Example in Mount Cameroon, studies have confirmed that medicinal plants used in the region are as efficient as the imported "Western" prescription medicine (NKuinkeu, 1999). Dzanga Sangha Complex Protected Area offers a rich pharmacopoeia. (Table 2)

\subsection{People's perception on the variables related to social aspect}

Taking into consideration the Pearson chi-square, the value close to 1 (1.935) suggest that education level is not dependent on which gender nor groups of age are involved. However, the likelihood that the two variables are dependent increases as Pearson Chi-Square value gets larger and larger. For example, the perception of Ba Aka people towards gender and education, the relationship between household age and gender and education with the value of $2.000 ; 5.349 ; 3.4326$ and 16.833 respectively. Similarly, according to the significance, the household age is dependent on education level because $(\mathrm{P}=0.032<0.05)$. (Table 3$), \mathrm{N}=180$

\subsection{Market}

Bayanga, the sub prefecture, had market and other villages near Bayanga like Yandoumbe, Mossapoula respectively $3 \mathrm{~km}$ and $5 \mathrm{~km}$ from Bayanga. However, Lidjombo $30 \mathrm{~km}$ from the market, Bomandjoukou $60 \mathrm{~km}$, Babongo $10 \mathrm{~km}$, Yondo $15 \mathrm{~km}$, and Yobe $17 \mathrm{~km}$. Market access can offer many income opportunities, which may decrease forest activities. (Gunatilake, 1998) said when people had access to outside market, it will reduce resources exploitation in the forest. Moreover, when the forest products increases, people will tend to extract more forest resources. (Figure10)

\subsection{Hunting income}

Bayanga has more than 333 hunters. However, this big number does not immediately relate to the increase of income from hunting activities because of a small number of frequencies that refer to the entry of hunters into the forest. Bayanga is the sub prefecture where Dzanga Sangha project is located and few local people from Bayanga were employed in the park Dzanga Sangha conservation project.

Bomandjokou which is far from Project Dzanga Sangha at $60 \mathrm{~km}$ with 50 hunters had the highest hunting income per year (\$674012.4) followed by Lidjombo ( 33 hunters with \$99408), Mossapoula (44 hunters with $\$ 93522)$, Babongo (29 hunters with \$60822), Yondo (10 hunters with \$19620), and Yobe (4 hunters with $\$ 11426)$.

In Bomandjoko, only $45 \%$ of people went to school and were not regular and took more time in hunting than agriculture. Yandoumbe and Mossapoula, even though they get more benefit from the National park Dzanga Ndoki, people are still involved in poaching activities. This situation revealed that the profit they got from the project were not enough to meet their needs. Because of many conflicts between conservationists and local people, economic incentives may play an important role in the establishment of a trust confidence between Dzanga Ndoki and the local people. However, as pointed out by De Wachter (1997), we must pay attention to the problem of "free rider". It means we can provide public goods to the community, but this does not prevent the commercial hunters from continuing to hunt. Then, there is no link between the public behavior of the hunter and the provision of public goods. This motto was frequently observed. Many authors offer support primarily to economic activities that do not conflict with the conservation of the ecosystem. In this perspective, I think it is better to stress agro forestry activities system to stabilize agricultural production and livestock such as rabbits, as well beekeeping. (Figure 11a)

Mogba (1996), Poaching for meat, ivory, and skins has been a major challenge to conserve the national park Dzanga-Ndoki.These activities are extremely lucrative, and guns, ammunition, and cable for snare are readily available. External market merchants have hunters under their control, often Ba Aka, who hunt almost exclusively for their boss who pay them. Hunters utilize various forms of hunting technologies, including rifles, snares, and traps. Rifle and snare hunting are especially widespread. A single hunter in Bayanga may have 200 steel snares and 3 of the locally manufactured guns. In Salo's Kouapili district; over $60 \%$ of the population possesses at least one firearm. These weapons have never been declared to the wardens, and are thus technically illegal. Setting 200 snares in a plentiful area, one hunter may catch between 40 and 80 different animals in one round of hunting. Hunters were often forced to abandon part of their catch because they cannot transport all the meat to market before it rots. Local communities claim that immigrant hunters believe in the perpetual regeneration of wild animal populations, and thus justify the acceleration of poaching in the reserve and national park Dzanga Ndoki. (Figure 11b)

\subsection{Agricultural income}

Bayanga with a big household size, has a highest agricultural income (\$42358.4) followed by Mossapoula \$5924.1, Lidjombo \$5077.8, Bomandjokou \$4231.5, Babongo \$3808.35, Yandoumbe \$3385.2, Yondo \$2115.75 and Yobe $\$ 846.3$.

However, not for all, some households with little agricultural income (case of Bomadjokou) have big household 
size. That means that a household with a high agricultural income is less dependent on forest resources, example of Bayanga. Household with limited income from agriculture depends more on forest resources to meet its needs (Gombia-Ssembajjwe, 2000). This is the case of Bomandjoukou. That is why hunting income in Bayanga is less than in Bomandjokou because Bayanga people took more time for agricultural activities. However, agricultural income in Bomandjokou is less than in Bayanga because they took more time for hunting. Also in Bayanga, there are small business and little opportunity to work in logging company (now closed for moment) or work in some NGOs.

In Bomandjoko, if the population has various resources income, they will reduce to poach and get less income from forest resources. (Figure 12)

4.9 Plants and fruits collection

People collect natural products for subsistence needs. People in Bayanga had $\$ 1584000$ per year for the wine raffia palm. Mossapoula, Yandoumbe had respectively \$147840 and \$ 79200 for plants and fruits collection per year.

Plants and fruits collection were the main source of income in Yandoumbe and Mossapoula because of their localization for easy access to market. Local people collected wine raffia and cultivate cassava first for subsistence, then for commercial use. They still depend on the forest because of lack of alternative activities, which offer many opportunities of job. If poor communities have diverse resources of income, they will extract less resource and get less income from the forest resources. According to Vedeld et al. (2003), environmental income decrease with increasing total households income. (Table 4)

4.10 People's perception on the variables related to economic aspect

The following values for significance $(\mathrm{P}=0.008 ; \mathrm{P}=0.001<0.05)$ suggest that hunting income variable is not independent on agricultural income nor plant and fruits collection respectively. As the Pearson chi-square values are very large for economic factors, there is then dependence of each variable on the other. (Table 5), $\mathrm{N}=180$

\subsection{Participative management}

4.11.1 Workers in Dzanga Sangha

Dzanga Sangha project managed by the Ministry of Waters, Forests, Hunting and environment of the Central African Republic, World Wide Fund for Nature (WWF) and the German Ministry of cooperation and development. Dzanga Sangha had 150 staff divided into 120 permanent and 30 temporaries. According to the results, most of these workers came from Bayanga villages (50 workers), Yandoumbe (40 workers), and Mossapoula (had 60 workers). The 5 other remote village except Bayanga, Yandoumbe and Mossapoula were marginalized because they did not have any representative workers in the project for the development of their communities. Dzanga Sangha was a model of participative management in protected area even tough there was a lack of effective management. (Figure 13)

\subsubsection{Perception of Ba Aka}

According to the table, Ba Aka people were 38. Then, 13 amounting to 34, 20\% were satisfied with the project. 23 respondents amounting to $60.52 \%$ were not satisfied with the project; 2 Ba Aka amounting to $5.26 \%$ answered that they don't Know any project. Ba Aka from Yandoumbe and Mossapoula already had one member of family who worked in the project. Most of Ba Aka were not employed in the project. That is why many Ba Aka reject the project. The Ba Aka would like to work as eco-guards to help protect their forest. On the other hand, Ba Aka were not satisfied because there was lack of consultation for all projects before starting the project in their village. (Nelson,2008) said : "There is no evidence that local and pygmies communities were consulted over these changes, or gave their consent for the subsequent restrictions on forest access population in Dzanga Ndoki, but there have been social costs".

The conservation plan agreement reviewed here were not in place in the late 1980s when the management plan for Dzanga Sangha was drawn up and when consent should have been sought. However, the Dzanga Sangha should now take the opportunity to review and amend park boundaries according to traditional ownership and following consent process outlined in this international agreement and WWF policy. (Table 6)

4.11.3 Assessment of stakeholders in Dzanga- Sangha

Stakeholders of Dzanga Ndoki National park were firstly the government represented by the Ministry of Water, Forest, Hunting, Fishing and environment. Afterwards, there were international or National NGOs finally the local people and minority people (pygmies).

\subsubsection{Government involvement}

This table 7 shows us how the ministry of Water, Forest, Hunting, Fishing and environment organizes controls the natural resources management.

The government enhances to maintain biodiversity through many texts or international convention signed with international NGO. For example: the government signed the RAMSAR convention to better protect its wetlands. Also tacked law No. 90,018 of 29 December established a Special Reserve of the dense forest Dzanga Sangha. 
CAR government suspended bidding process for all open logging concessions in Dzanga Sangha reserve. (Table 7)

\subsubsection{Dzanga Sangha project}

The Dzanga Sangha project is an integrated project conservation and development project, meaning that there should be a particular attention paid to local people, the projects involved and NGO's in the conservation. The project activities were reinforced starting in 1994 with the arrival of GTZ (the German Development Agency). Dzanga Sangha project get technical support and financial support from numerous donors agencies: (the Government of CAR, Germany and USA; private donors; and WWF-US-Germany, WWF-US, FFEM/CAWHFI and Netherlands as well as WCS- Wild life Conservation Society). (Table 8)

\subsection{3 International NGO's in Dzanga Ndoki Conservation}

This table shows the principal international NGO, which intervened in Dzanga Ndoki conservation and Special Reserve Dzanga Sangha. Moreover, the main activities they are doing. Where these International NGO have got their financial support as well.

The Success history of the most popular one called CARPE: 18 March 2006, a WWF Delegation consisting of Laurent Some, Guillermo Castilleja, Lavinia Currier, Jean Bernard Yarissem, Richard Carroll and Allard Blom was received by President of Central African Republic to present a proposal for the Sustainable Development of the Dzanga-Sangha Reserve. There was a proposal, which would retire the unsustainable commercialized timber exploitation from within the Dzanga Sangha Special Reserve indefinitely. The proposal also clearly noted donor flexibility in supporting other options, such as relocation of the mill outside of the reserve, and assistance to a new logging company moving towards sustainable practices (economical, social as well as environmental) and in obtaining forestry certification. The government has not acted upon the offer; however, the concession has also not yet been attributing. (Table 9)

\subsubsection{National NGO's in Special Reserve}

These principal National NGOs with their designation, when they were created, what they are doing and where they had got financial resources. Only two, AIDECOR had support from CARPE and UICN, while (ADLAC) got it from Dzanga project.

This table showed only few National NGO's have intervened in Dzanga Sangha management or support the conservation project. This lack of participation for many NGOs in the Dzanga Sangha project is that they do not get or get very low financial support from the project. (Table 10)

\subsubsection{Associations for local people}

As a whole, the government increasingly recognizes NGOs as competent partners. The major ambiguity in their relationship with the government is because the latter tends to see them as adversaries, while considering that NGOs must assist government to develop their locality or city. In addition, Central African Republic registration of NGOs suffers from many problems (administratively, blend of all type of association).

While The Government and the project Dzanga Sangha claim that it is in favor of National or local NGO to develop and support Dzanga Ndoki conservation, they take few measures to facilitate their development (no financing or low financing). On the other hand, donors feel that funds they can make available for National NGO's surpass the absorption capacity of the NGOs (absorption capacity includes the capacity in meeting donor requirement and methodology).

Many Associations are located in Bayanga. This situation is not at all good for the conservation project. These Associations have lack of money to become more powerful in the implementation in their development program. Most of them focus on agriculture, but professional assistant technical would be better to their success. (Table 11)

The Strengths and weaknesses of these stakeholders are as follows:

4.11.3.6 Strengths and weaknesses of stakeholders involved in Dzanga Sangha. (Table 12)

\section{Conclusions}

It is important to consider a broader array of assets in order to identify people living around Dzanga Ndoki National park depending on forest resources for their livelihoods.

Socioeconomic factors show that incomes from forest resources are important in situation where people are unable to obtain sufficient income, from agriculture or wage employment. In our case, 150 people who were working in the Project were insufficient. Understanding the dependency of households on the park is critical for developing management strategies. Our study found out that households in the village with higher income are more dependent on the park for instance Bomadjokou village

(674012.4). Furthermore, income from agriculture and access to outside markets will reduce natural resources income, the case of Bayanga (75864). People between 20-25 age (36.55\%) and those within 25-30 age represent $(27.81 \%)$. The Collection of products in the park was restricted; therefore, the elderly people did not take the risk 
to enter into the park. Approaches of restricting access to the park will only escalate "park people" conflicts.

Participation in the project has been minimal, with no channel of communication between the Ba Aka minority people and the project. Most consultation is concentrated in Mossapoula and Yandoumbe. Only these 2 villages (Mossapoula, Yandoumbe) out of 8 in the Special Reserve got profit of the project. For example in Mossapoula and Yandoumbe 100 people are employed by the project. Ba Aka customary land ownerships appear not to have informed National park conservation. Ba Aka minority people (60.52\%) were not satisfied with the project, 34 , $20 \%$ were satisfied with the project and $5.26 \%$ do not know any project. In addition, access to land is today a key problem for all Ba Aka communities. Ba Aka would like to work as eco-guards.

National NGOs and Associations have ability for voluntaries works for their local, communal, regional development but still weak collective group without financial support to implement their program. Government that has capacity and capabilities to influence the project in the management process is still opportunist and the project suffers from ineffective management even tough Dzanga Sangha project is a model of participative management in the region .

\section{References}

Blom, A., Ten years Dzanga Sangha Project: 1988-1999. World Wildlife Fund, Bangui, CAR.

Blom, A., Yamidou. J., Prins. Herbert H. T. (2004). Status of the protected areas of the Central African Republic. Biological Conservation 118 (2004):479-487.Department of Terrestrial and Nature Conservation, Wageningen University, Bornsesteeg 69,6708 PD Wageningen, The Netherlands Department of Anthropology, State University of New York at Stony Brook, NY 11794, USA World Wildlife Fund, POBOX 1053, Bangui, Central African Republic.

Blom. A., Yamidou, J. (2001). History of Armed Conflict and its impact on Biodiversity in the Central African Republic. Washington,D.C.: Biodiversity Support Program.

Carroll, R.W. (1997). Feeding Ecology of the western lowland gorilla (Gorilla, gorilla, gorilla), in the Central African Republic. Yale University, New Haven, CT.

Carroll, R. (2003). World Wildlife Fund (WWF-US). Organizational Overview: Dzanga Sangha Reserve, Central African Republic, Sangha River Region, in Yale F\&ES Bulletin 102,198-207.

Cracraft, J. (1995). The Urgency of Building Global Capacity for Biodiversity Science, Biodiversity and Conservation 4: 463-475.

Eyong, C.T. (2007). Indigenous Knowledge and Sustainable Development in Africa: case study of Central Africa. Tribes and Tribal, Special vol.: 121-139 (2007).

George, D., Mallery. Paul. (2006). Spss for Windows Step-by-Step: A simple Guide and reference, 13.0 Update ISBN 978-7-5062-8219-2

Gunatilake, H.M. (1998). The Role of Rural Development in Protecting Tropical Rainforests: Evidence from Sri Lanka. Journal of Environmental Management.53: 273-292.

Gombya-Ssembajjwe, W.S. and Banana,A.Y. (2000). (Eds.). In Community Based Forest Resources Management in East Africa, Kampala, Uganda: Makerere University Press.

Hardin, R. R, Melissa. (1998). Report of Research and Rural Development Work Sessions, Dzanga Sangha Dense Forest Reserve, Central African Republic. Yale University Council on International and Area Studies/Sangha River Network $<$ http://www.yale.edu/sangha $>$.

Kamiss, A. Turkalo, A.k. (1999). Elephant Crop Raiding in the Dzanga-Sangha Reserve, Central African Republic. Associate Conservation Scientist, Wildlife Conservation Society, POBOX 1053 Bangui, Central African Republic.

Kamiss, A. (2006). Census of villages in the Special Reserve Dzanga Sangha. Project Dzanga Sangha Report, 26pp.

Mosozera, M. K., Alavapati, Janaki R. R., Jacobson, S. K. Shrestha, R. K. (2006). Assessing the Sustainability of Community-based management for the Nyungwe Forest Reserve, Rwanda. Forest Policy and Economic 8: (2006) 206-216.

Mogba, Z., Freudenberger.M. (1989). Human Migration in Protected Zones of Central African: the case of the Dzangha Sangha Special Reserve, Bulletin 102. Yale.

Ndinga, A. (1988). Managing protected areas in Africa. POBOX 2298 Rep. of Congo.

Noss, A.J. (1997). The Economic Importance of Communal net Hunting among the Ba Aka of the Central African Republic. Human Ecology, Vol 25. 00300-7839/97/030071.

Nelson, J. (2008). Consultations Report of communities in Complex Dzanga Sangha Protected Area. Forest peoples Program.1c Fosse way Business. Center, Stratford Road, Moreton-in-Marsh GL569NQ, England.

Patrice Ch. (2000). Dzanga-Sangha Protected Areas Central African Republic. WWF Germany, Rebotocker 
Straße 55, D-60326 Frankfurt am Main. Rochstroh + partner GmbH, D-61479 Glashuteten im Taunus, 60p.

Reardon, T., and S. Vosti. (1995). Links between Rural Poverty and the Environment in Developing Countries. World Dev., 23:1495-1506.

Struhsaker, T.T., Struhsaker, Paul. J., Kerstin. S. (2005). African rain forests: problems in protected areas and possible solutions. Biological Conservation 123: (2005)45-54.

Woodburne, O. (2009). Securing Indigenous People' right in Conservation: Review of Policy and implementation in the Dzanga-Sangha Protected Area Complex. Forest Peoples Program, 1c Fosse way Business Center. Stratford Road, Moreton-in-Marsh GL569NQ. United Kingdom.

WWF, CARPE. (2006). Phase II/WWF/Report/Final/CAR, No Focal point FY04 and FY05, Focal point FY06.

IUCN. (1994). Guide line for protected areas management.

IUCN, Cambridge, UK and Gland, Switzerland.

Table 1. Presentation of the park

\begin{tabular}{|c|c|}
\hline Country & Central Africa Republic \\
\hline Name of Park & National park Dzanga-Ndoki and Special forest Reserve Dzanga Sangha \\
\hline Decrees & $\begin{array}{l}\text {-Law No. 90,017 of 29/12/90 establishing the National park Dzanga-Ndoki (Dzanga sectors } \\
\text { and Ndoki); } \\
\text {-Decree NO. } 008 \text { standing order of the National park; } \\
\text {-Law No.90,018 of 29/12/90 establishing a Special Forest Dense Dzanga Sangha (RSFD) } \\
\text { Decree No.008 concerning rules of Special Reserve Dzanga Sangha }\end{array}$ \\
\hline $\begin{array}{l}\text { Creation Date } \\
\text { (history) }\end{array}$ & $\begin{array}{l}\text { Figure on the tentative list of world heritage sites proposed to UNESCO by the governments } \\
\text { Cameroon and Central Africa Republic }\end{array}$ \\
\hline $\begin{array}{l}\text { Location } \\
\text { Geographic }\end{array}$ & $\begin{array}{l}\mathrm{N}-\mathrm{E}=16.58,340 / \mathrm{N}-\mathrm{O}=15.70 ; 3.40 \\
\mathrm{~S}-\mathrm{E}=16.58,2.21 / \mathrm{S}-\mathrm{O}=15.70 ; 2.21 \\
445,000 \text { ha of which, National park Dzanga Ndoki }=125,000 \text { ha and Special Reserve } \\
\text { rainforest Dzanga. Sangha }=320,000 \text { hectares } \\
\text { Located in the Prefecture Sangha-Mbaere, Sub Prefecture Bayanga; Common Yobe-Sangha } \\
\text { South-west of Central Africa Republic }\end{array}$ \\
\hline $\begin{array}{l}\text { Means of } \\
\text { Access (roads, } \\
\text { stations, } \\
\text { railway rail, } \\
\text { Airport, river) }\end{array}$ & $\begin{array}{l}500 \mathrm{Km} \text { by forest tracks and roads of the 4th parallel Mbaiki, Boda Bambio, Nola, Bayanga. } \\
10 \text { hours drive } \\
1 \text { hour } 30 \text { min flight from Bangui. }\end{array}$ \\
\hline Landscape & $\begin{array}{l}\text { Rivers Sanga, No.5 } \\
\text { The Trinational Sangha ( TNS )has been created on initiative of the } \\
\text { WCS, WWF and the respective Governments. It was officially recognized by the Cooperation } \\
\text { Agreement of NER, Signed in December } 2000 \text { when first COMIFAC (Forestry Commission } \\
\text { of Central Africa). NER is composed of National park Dzanga Ndoki Central Africa } \\
\text { Republic, the National park Nouabele-Ndoki Republic of Congo (Brazzaville), National park } \\
\text { Lobeke in Cameroon and their peripheral areas with multiple uses. }\end{array}$ \\
\hline $\begin{array}{l}\text { Management } \\
\text { plan/planning in } \\
\text { development } \\
\text { IUCN }\end{array}$ & 2 \\
\hline $\begin{array}{l}\text { G200 } \\
\text { Ecoregion }\end{array}$ & No 23 , Congo Basin \\
\hline $\begin{array}{l}\text { Details on the } \\
\text { Property }\end{array}$ & Public areas of the state \\
\hline $\begin{array}{l}\text { Institute } \\
\text { management }\end{array}$ & $\begin{array}{l}\text { Project Pasterns Dzanga Sangha, Placed under the Ministry of water, forest, hunting and } \\
\text { fishing }\end{array}$ \\
\hline
\end{tabular}

Source: (Kamiss, 2005) 
Table 2. Medical plants use in the Special Reserve

\begin{tabular}{|c|c|c|}
\hline Scientific name/common name & Part of plant used & Medical use \\
\hline Pterocarpus Soyauxii (Padouk,or Camwood) & Ground stem & Child birth, marriages \\
\hline Terminalia superba (Frake) & Bark & Anti dote \\
\hline (Garcinia kola) Bitter Kola & seeds & Digestives anti-poison antidote \\
\hline Chytranthus gilletii ( Moseke) & leaves & Cough \\
\hline Melicia excelsa (iroko) & Most sacred tree species & Sacrifices to appease gods \\
\hline Entandrophragma cylindricum (sapelli) & Bark & Cough, malaria \\
\hline Nauclea diderrichii (bilinga) & $\begin{array}{l}\text { Bark, roots, and wood or } \\
\text { trunk }\end{array}$ & Fever, stomach problem \\
\hline Polyalthia suaveolens (motunga) & bark & child headache \\
\hline Cnestis genus (Elende) & leaves & Cardiac trouble, \\
\hline Garcinia punctata (munkata ) & Bark & Diarrhea \\
\hline Lophira alata (azobe or ironwood) & Trunk & $\begin{array}{l}\text { Medicine for back pain, } \\
\text { toothache }\end{array}$ \\
\hline Aframomum spp & leaves & $\begin{array}{l}\text { Spice for food, coughs, } \\
\text { magnifier in medicinal mixtures }\end{array}$ \\
\hline Rothmannia witifielddii (Didembe) & Sap & Tattoos on the face \\
\hline Autrenella (Mukulungu) & Bark & Malaria \\
\hline
\end{tabular}

Selected plants and their traditional use found in the Special Reserve Dzanga Ndoki

Table 3. People's perception on the variables related to social aspect $(\mathrm{N}=180)$

\begin{tabular}{llcc} 
Variables vs variables & Pearson chi-square & df & Significance \\
\hline Education - Gender & 1.935 & 2 & 0.380 \\
Education - Household age & 1.935 & 2 & 0.380 \\
Household Age - Education & 16.833 & 8 & 0.032 \\
Household Age - Gender & 3.426 & 4 & 0.489 \\
Ba Aka - Education & 5.349 & 4 & 0.253 \\
Ba Aka -Gender & 2.000 & 2 & 0.368
\end{tabular}

Table 4. Plants and fruits collection

\begin{tabular}{|l|l|l|l|l|}
\hline villages & Plants or fruits & $\begin{array}{l}\text { Number of } \\
\mathrm{kg} \\
\text { month }\end{array}$ & $\begin{array}{l}\text { Number of kg per } \\
\text { year }\end{array}$ & $\begin{array}{l}\text { Amount } \\
\text { money in } \\
\text { \$ per year }\end{array}$ \\
\hline Bayanga & "Molengue" wine raffia & 600000 & 7200000 & $1.584 .000,00$ \\
\hline Yandoumbe & $\begin{array}{l}\text { Mushroom(auriculoria,collybia),Koko } \\
\text { leaves(gnetum buclolzianum ), wild } \\
\text { yams (Dioscora spp), }\end{array}$ & 15000 & 180000 & 79200 \\
\hline Mossapoula & $\begin{array}{l}\text { Honey "kossa" (Mamiophtyon } \\
\text { macrostachyum), Caterpillard(Imbrasia } \\
\text { oyemensis, Imbrasia truncate), } \\
\text { terminalia superba, Entandrophragma } \\
\text { cylindricom. }\end{array}$ & 103000 & 736000 & 147840 \\
\hline Total & $-\quad$ & & 1811040 \\
\hline
\end{tabular}

Plants and fruits collection income 
Table 5. People's perception on the variables related to economic aspect $(\mathrm{N}=180)$

Variable vs variable

Pearson chi-square

df Significance

Hunting income-Market Access

543.238

553

0.608

Hunting income-Agricultural income

3680.722

346

0.008

Hunting income-Plant and fruits

4095.588

3822

0.001

Collection

Market access-Agricultural income

368.599

462

0.999

Market access-Plant and fruits

316.243

343

0.843

Collection

Plant and fruits collection-Agricultural 2043.524

2107

0.836

Income

Table 6. Perception of Ba Aka (minority people or pigmies' people)

\begin{tabular}{|l|l|l|l|l|}
\hline Villages & \multicolumn{3}{|c|}{ Perception } & \multirow{2}{*}{ Total } \\
\cline { 2 - 4 } & $\begin{array}{l}\text { Satisfied with } \\
\text { the project }\end{array}$ & $\begin{array}{l}\text { Not satisfied with } \\
\text { the project }\end{array}$ & $\begin{array}{l}\text { I don't know } \\
\text { any project }\end{array}$ & \\
\hline Yandoumbe & 7 & 1 & 0 & 8 \\
\hline Mossapoula & 6 & 2 & 1 & 9 \\
\hline Lidjombo & 0 & 6 & 0 & 6 \\
\hline Bomandjokou & 0 & 6 & 1 & 7 \\
\hline Yondo & 0 & 4 & 0 & 4 \\
\hline Yobe & 0 & 3 & 2 & 3 \\
\hline Total & 13 & 23 & & 38 \\
\hline
\end{tabular}

The $\mathrm{Ba}$ Aka perception and their villages

Table 7. Government involvement

\begin{tabular}{|c|c|c|c|c|}
\hline Actors & Field intervention & Type of intervention & Target Zone & Financing/co Financing \\
\hline MEFCPE & $\begin{array}{l}\text { Ministry of water, } \\
\text { Forest, Hunting, } \\
\text { Fisheries and } \\
\text { environment }\end{array}$ & $\begin{array}{l}\text { 4 branches } \\
\text { Waters, forests, } \\
\text { hunting, fishing and } \\
\text { AP Regional Services } \\
\text { Support General } \\
\text { Direction services }\end{array}$ & & $\begin{array}{l}\text { CCAS-DFT } \\
\text { State Project trust } \\
(\text { ECOFAC) }\end{array}$ \\
\hline Conservation & $\begin{array}{l}\text { Management and } \\
\text { conservation }\end{array}$ & $\begin{array}{l}\text { Monitoring against } \\
\text { poaching, managing a } \\
\text { team of } 32 \text { eco-guards } \\
\text { with } 8 \text { sections. } \\
\text { Interview of } \\
\text { attractions, facilities } \\
\text { and trails park }\end{array}$ & $\begin{array}{l}\text { National } \\
\text { park Dzanga } \\
\text { Ndoki and } \\
\text { special } \\
\text { reserve } \\
\text { Dzanga } \\
\text { Sangha }\end{array}$ & $\begin{array}{l}\text { MEFCP,WWF,GFA/GT } \\
\mathrm{Z}+ \\
\text { Receipts Tourism }\end{array}$ \\
\hline
\end{tabular}

Government organization for managing Dzanga Sangha 
Table 8. Dzanga Sangha project

\begin{tabular}{|c|c|c|c|c|}
\hline Actors & $\begin{array}{l}\text { Fields of } \\
\text { intervention }\end{array}$ & Type of intervention & $\begin{array}{l}\text { Actions- } \\
\text { Target } \\
\text { zone }\end{array}$ & $\begin{array}{l}\text { Funding/ } \\
\text { co } \\
\text { financing }\end{array}$ \\
\hline \multirow{6}{*}{$\begin{array}{l}\text { Dzanga- } \\
\text { Sangha } \\
\text { Project } \\
\text { (PDS) } \\
\text { Created } \\
\text { in } 1988\end{array}$} & \multirow{6}{*}{$\begin{array}{l}\text { Sustainable } \\
\text { development }\end{array}$} & $\begin{array}{l}\text {-Sustainable Development } \\
\text { Support for economic stabilization and ecological } \\
\text { zone for the populations riparian and biodiversity } \\
\text {-Develop pattern of land use for the NER and a local } \\
\text { plan development for the city of Yobe Sangha } \\
\text { Achieving micro project of community and } \\
\text { communal coastal populations (schools, health } \\
\text { center, water supply etc...) }\end{array}$ & $\begin{array}{l}\text { Special } \\
\text { reserve } \\
\text { Dzanga } \\
\text { Sangha }\end{array}$ & $\begin{array}{l}\text { GTZ/GF } \\
\text { A }\end{array}$ \\
\hline & & $\begin{array}{l}\text { - Conceptualization and implementation of database } \\
\text { mapping and GIS } \\
\text {-Support the development of the management plan } \\
\text { and management of Complex Protected Area } \\
\text { Dzanga Sangha }\end{array}$ & $\begin{array}{l}\text { Special } \\
\text { reserve } \\
\text { Dzanga } \\
\text { Sangha }\end{array}$ & $\begin{array}{l}\text { GTZ/GF } \\
\text { A }\end{array}$ \\
\hline & & $\begin{array}{l}\text { Special Reserve Dzanga Sangha GTZ/ GFA } \\
\text { Socioeconomic studies on demographic trends, } \\
\text { affects tourism and the damage caused by elephants. } \\
\text { Management of library collection and compilation of } \\
\text { documents }\end{array}$ & $\begin{array}{l}\text { Villages } \\
\text { of } \\
\text { Special } \\
\text { reserve }\end{array}$ & GTZ \\
\hline & & $\begin{array}{l}\text { Program of support local development initiatives: } \\
\text {-making agricultural training } \\
\text {-Allocation of } 40 \% \text { in social work and support } \\
\text { micro-projects (school supplies, educational } \\
\text { materials etc...) } \\
\text {-Support the development of basic documents + } \\
\text { development of micro-projects associations: + } \\
\text { alternative activities to hunting (small livestock } \\
\text { farming) to reduce the human impact pressure on the } \\
\text { park }\end{array}$ & $\begin{array}{l}\text { Local } \\
\text { associati } \\
\text { on } \\
\text { school, } \\
\text { health } \\
\text { Center } \\
\text { Terminal } \\
\text { Associati } \\
\text { on }\end{array}$ & $\begin{array}{l}\mathrm{GTZ}+40 \\
\% \text { of the } \\
\text { fund }\end{array}$ \\
\hline & & $\begin{array}{l}\text { Program communication and environmental } \\
\text { education: awareness of the protected of the } \\
\text { environment conservation, health and education, } \\
\text { poaching } \\
\text { Tools and screening films, textbooks on the } \\
\text { protection, regulation, directories protected species, } \\
\text { programmed to display park entrance, information } \\
\text { leaflets club of Nature in Bayanga includes } 30 \\
\text { children :information on the forest plants, animals } \\
\text { Visit the saline conducted with a facilitator twice a } \\
\text { year }\end{array}$ & $\begin{array}{l}\text { All } \\
\text { public } \\
\text { and } \\
\text { cover the } \\
\text { entire } \\
\text { area } \\
\text { Reserve } \\
\text { +village } \\
\text { Outs kits }\end{array}$ & GTZ \\
\hline & & $\begin{array}{l}\text { Program for sustainable forest and wildlife } \\
\text { resources: } \\
\text {-Study the importance of NTFPs by households of } \\
\text { different villages in the Reserve; } \\
\text {-Organization of fishermen along the Sangha: } \\
\text { Census of camps fishermen, fishery resource } \\
\text { inventory, development support activities fishing; } \\
\text {-Supervision of the organization of village } \\
\text { development plans: Mapping } \\
\text {-Participatory village land; management of the } \\
\text { agricultural zone (strip cropping): monitoring of } \\
\text { activities regulated }\end{array}$ & $\begin{array}{l}\text { Village } \\
\text { of } \\
\text { National } \\
\text { Reserve }\end{array}$ & $\begin{array}{l}\text { GTZ } \\
\text { WCS } \\
\text { FFEM/ } \\
\text { CAWHFI } \\
\text { WWF }\end{array}$ \\
\hline
\end{tabular}

Dzanga Sangha Project and his different types of activities 
Table 9. International NGOs in Dzanga Ndoki conservation

\begin{tabular}{|c|c|c|c|c|}
\hline Actors & Field intervention & Type of intervention & Action target zone & $\begin{array}{l}\text { Funding/co } \\
\text { financing }\end{array}$ \\
\hline WCS & Conservation and search & $\begin{array}{l}\text { Research project on } \\
\text { identifying elephant Dzanga } \\
\text { Bai and implementation of } \\
\text { database, data national park } \\
\text { photographic }\end{array}$ & $\begin{array}{l}\text { National park } \\
\text { Dzanga Ndoki }\end{array}$ & WCS \\
\hline $\begin{array}{l}\text { CAWHFI/ } \\
\text { UNESCO }\end{array}$ & $\begin{array}{l}\text { Initiative Heritage World } \\
\text { Forestry Central Africa }\end{array}$ & $\begin{array}{l}\text {-Registration TNS World } \\
\text { Heritage Cross-border } \\
\text {-Cooperation } \\
\text { coordination } \\
\text {-Develop a program for } \\
\text { implementation and } \\
\text { monitoring of sustainable } \\
\text { management, fisheries in } \\
\text { Tri-National Sangha } \\
\text {-Support the conservation } \\
\text { and management of the park } \\
\text { Dzanga Ndoki }\end{array}$ & $\begin{array}{lr}\text { Special } & \text { Reserve } \\
\text { Dzanga } & \text { Sangha }+ \\
\text { TNS } & \end{array}$ & $\begin{array}{l}\text { Special Reserve } \\
\text { Dzanga Sangha }\end{array}$ \\
\hline Carpe & $\begin{array}{l}\text { Conservation and } \\
\text { preservation biodiversity } \\
\text { in the Congo Basin }\end{array}$ & $\begin{array}{l}\text { Support project } \\
\text { implication of with } \\
\text { innovations for sustainable } \\
\text { natural resources proposed } \\
\text { by the project } \\
\text { Sangha }\end{array}$ & $\begin{array}{l}\text { Special Reserve } \\
\text { Dzanga Sangha }\end{array}$ & IUCN/USAID \\
\hline $\begin{array}{l}\text { Ecofac1.2.3 } \\
1999-2000\end{array}$ & $\begin{array}{l}\text { Central African Forest } \\
\text { Ecosystem }\end{array}$ & $\begin{array}{l}\text { Project tracking elephants } \\
\text { with GPS collars }\end{array}$ & $\begin{array}{l}\text { Area border areas } \\
\text { Protecting Dzanga } \\
\text { Ndoki (C.A.R) and } \\
\text { Nouabale-Ndoki } \\
\text { (Congo) }\end{array}$ & EU \\
\hline Mike 2004 & $\begin{array}{l}\text { Monitoring illegal } \\
\text { killing of elephant } \\
\text { species }\end{array}$ & & & \\
\hline
\end{tabular}

Table 10. National NGOs in Special Reserve

\begin{tabular}{|c|c|c|c|c|}
\hline Actors & $\begin{array}{l}\text { Field } \\
\text { intervention }\end{array}$ & Type of intervention & Target zone & $\begin{array}{l}\text { Funding/co } \\
\text { financing }\end{array}$ \\
\hline AIDECOR & Actions for & -Support for the involvement of pygmies & Local communities & CARPE/IU \\
\hline $\begin{array}{l}\text { Created in } \\
2001\end{array}$ & $\begin{array}{l}\text { Initiative } \\
\text { Developme } \\
\text { nt } \\
\text { Communiti } \\
\text { es Rural }\end{array}$ & $\begin{array}{l}\text {-Innovation for sustainable Natural } \\
\text { resources Capacity building for pigmies } \\
\text { (minority people) management } \\
\text {-Sustainable Natural resources at the TNS } \\
\text { trough training and the establishing of } \\
\text { micro-projects }\end{array}$ & $\begin{array}{l}\text { Special Reserve } \\
\text { Dzanga Sangha }\end{array}$ & $\mathrm{CN}$ \\
\hline ADLAC & $\begin{array}{l}\text { Association } \\
\text { Legal } \\
\text { owners } \\
\text { hunting } \\
\text { weapons }\end{array}$ & $\begin{array}{l}\text {-Advocacy common Meetings } \\
\text {-Awareness of legal hunting, protection of } \\
\text { species, fully protected } \\
\text {-Awareness of the population to benefit } \\
\text { the park and the interest of conservation }\end{array}$ & $\begin{array}{l}\text { Group of } 35 \\
\text { members } \\
\text { Action in the } \\
\text { village located } \\
\text { around National } \\
\text { park Dzanga Ndoki }\end{array}$ & $\begin{array}{l}\text { Devices } \\
\text { support } \\
\text { Dzanga } \\
\text { Sangha } \\
\text { project }\end{array}$ \\
\hline $\begin{array}{l}\text { Association } \\
\text { Ngai ne Kome } \\
\text { ("Effort arm") } \\
1996\end{array}$ & Food crops & $\begin{array}{l}\text {-Cassava, maize, peanuts, -Creating a } \\
\text { common fund and purchase of land } \\
\text { cultivation, partly for construction of } \\
\text { warehouse (seeking support) }\end{array}$ & Bayanga people & \\
\hline
\end{tabular}


Table 11. Association for local people

\begin{tabular}{|l|l|l|l|l|l|}
\hline Actors & $\begin{array}{l}\text { Fields } \\
\text { intervention }\end{array}$ & Types of intervention & Target-Zone & $\begin{array}{l}\text { Financing co } \\
\text { financing }\end{array}$ & Respondents \\
\hline UNAMIC & Grouping & $\begin{array}{l}\text { Agricultural and } \\
\text { fishing activities }\end{array}$ & Bayanga & $\begin{array}{l}\text { No financial } \\
\text { support }\end{array}$ & $\begin{array}{l}\text { Jean-Claude } \\
\text { Wanobilo }\end{array}$ \\
\hline IDEAC & Grouping & $\begin{array}{l}\text { Agricultural and } \\
\text { fishing activities }\end{array}$ & Bayanga & $\begin{array}{l}\text { No financial } \\
\text { support }\end{array}$ & $\begin{array}{l}\text { Bozi } \\
\text { Bewossongo }\end{array}$ \\
\hline $\begin{array}{l}\text { Fishermen } \\
\text { Bayanga }\end{array}$ & Grouping & Activities Fishing & Bayanga & $\begin{array}{l}\text { No financial } \\
\text { support }\end{array}$ & Germaine Lolo \\
\hline $\begin{array}{l}\text { Farmers } \\
\text { Association }\end{array}$ & Grouping & Agriculture improved & Bayanga & $\begin{array}{l}\text { No financial } \\
\text { support }\end{array}$ & $\begin{array}{l}\text { Theophille } \\
\text { Amiendi }\end{array}$ \\
\hline $\begin{array}{l}\text { AMM } \\
\text { The hand in }\end{array}$ & business activities & Bayanga & $\begin{array}{l}\text { No financial } \\
\text { support }\end{array}$ & Patrick Pives \\
\hline
\end{tabular}

Table 12. Strength and weakness of NGO involved in Dzanga Sangha

\begin{tabular}{|c|c|c|}
\hline Stakeholders & Strength & Weaknesses \\
\hline Government & $\begin{array}{l}\text {-Willingness } \\
\text {-Capacities and capabilities to take } \\
\text { decision } \\
\text {-Adhesion to international and } \\
\text { regional organizations }\end{array}$ & $\begin{array}{l}\text {-Opportunism } \\
\text {-Do not signed agreement easily to } \\
\text {-National NGOs } \\
\text {-Few technical skills in environment } \\
\text {-Not or few support to National NGOs } \\
\text { (necessitating at times politicization to } \\
\text { seek support) }\end{array}$ \\
\hline $\begin{array}{l}\text { International (NGOs; } \\
\text { project Dzanga Sangha, } \\
\text { Donors) }\end{array}$ & $\begin{array}{l}\text {-Outreach capacity toward local } \\
\text { people. } \\
\text {-Dynamism } \\
\text {-Capacity for suggestion to } \\
\text { government about unsustainable } \\
\text { logging }\end{array}$ & $\begin{array}{l}\text {-Poor management of the project } \\
\text {-Lack of consultation at all level for } \\
\text { participative management } \\
\text {-Lack of financing or co financing } \\
\text {-National NGOs and Association to } \\
\text { support the project }\end{array}$ \\
\hline $\begin{array}{l}\text { National NGOs and } \\
\text { Associations }\end{array}$ & $\begin{array}{l}\text {-Dynamism for learning capacity } \\
\text { regarding environmental issues } \\
\text { ( e.g. mapping) } \\
\text {-Capacity to mobilize human } \\
\text { resources (Local people, pygmies } \\
\text { minority people, young groups ) } \\
\text {-Support the actions taken by the } \\
\text { government or conservation of } \\
\text { Dzanga Sangha Project } \\
\text {-Ability for voluntaries works for } \\
\text { their local, communal, regional } \\
\text { development. }\end{array}$ & $\begin{array}{l}\text {-Weak collective group: self-proclaimed } \\
\text { group } \\
\text {-Lack of credibility (due to the } \\
\text { overwhelming number of NGOs } \\
\text {-Lack of means (confusion between } \\
\text { NGO and Association) } \\
\text {-Internal problem (cult of personality) } \\
\text {-Lack of financing or co financing } \\
\text {-Lack of experience } \\
\text {-Totally relying for external funding or } \\
\text { project Dzanga Sangha (little internal } \\
\text { support) } \\
\text {-Lack of information, communication } \\
\text { and cooperation among external NGOs } \\
\text {-Insufficient reflection and clear policy } \\
\text { choices } \\
\text {-Difficulty in self-analysis and involving } \\
\text { according to external environment } \\
\text { opportunities strategies }\end{array}$ \\
\hline
\end{tabular}




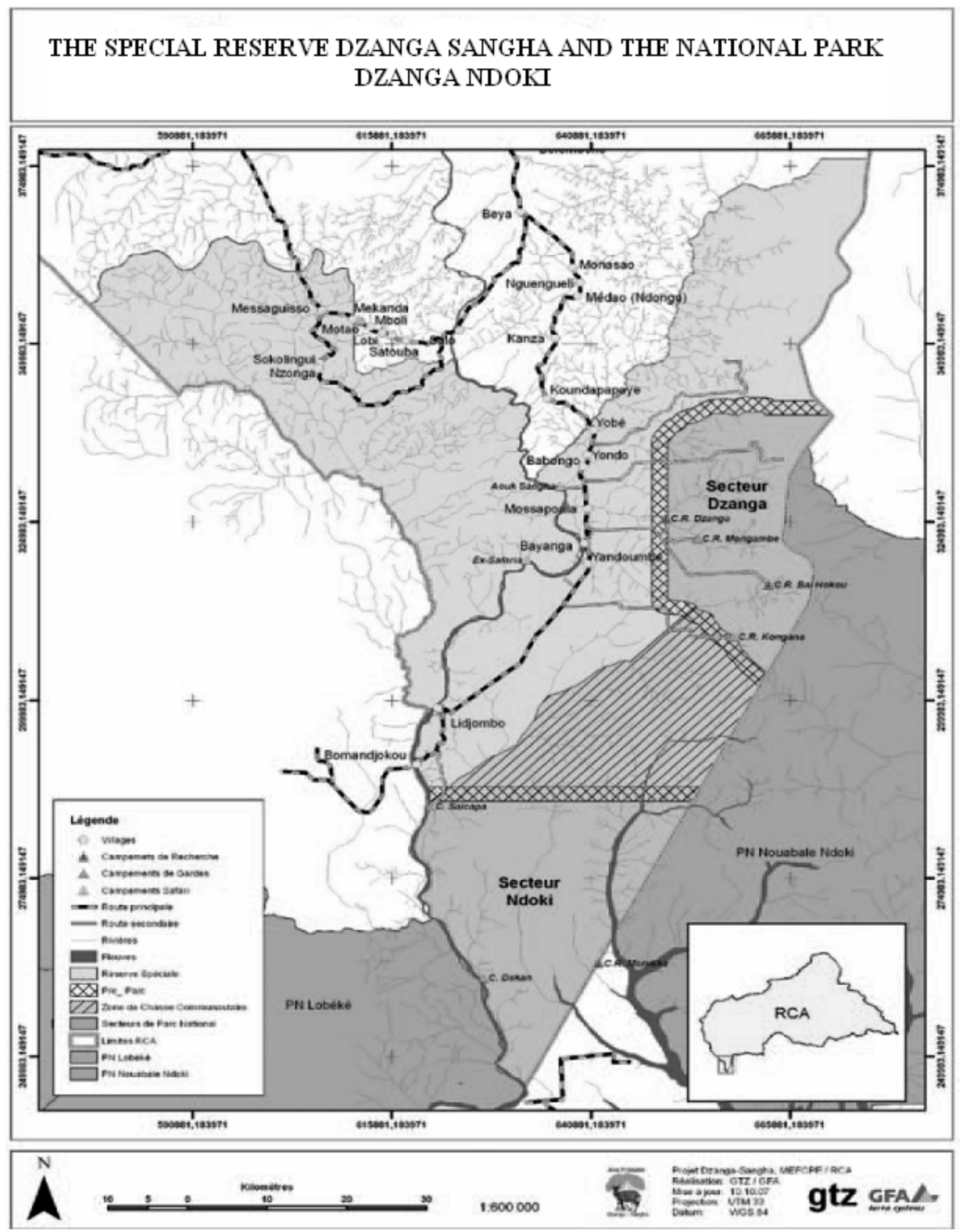

Figure 1. Source: Moaza and Sidemo (2006)

Dzanga Sangha Protected Area Complex (DSPAC) showing both national sectors and the reserve including the community hunting zone. The main river is Sangha the community within the reserve are situated along the road which runs next to the to river : Lidjombo and Bomadjokou to the bordering Cameroon; Yandoumbe and Mossapoula either side of Bayanga; and Babongo, Yondo and Yobe to the north 


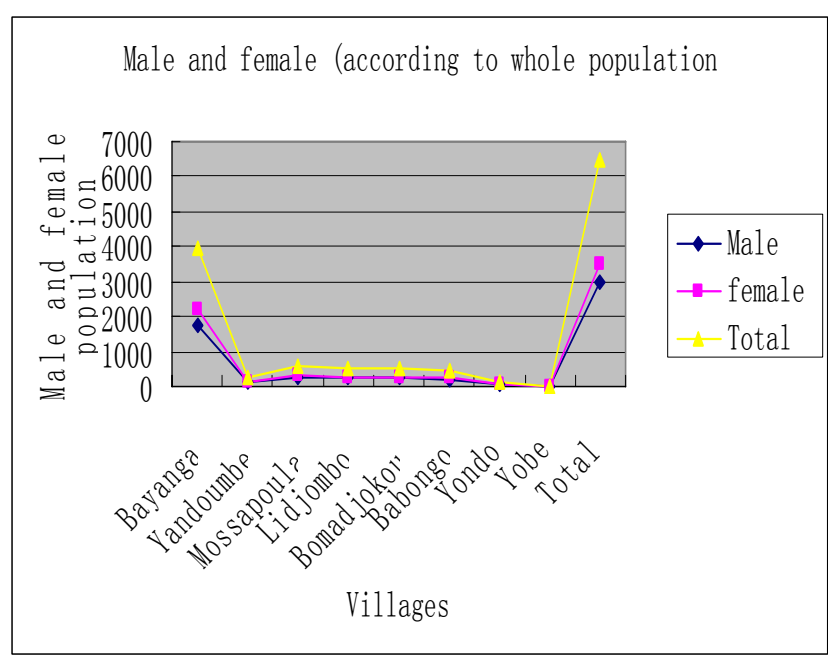

Figure 2. Dzanga Sangha populations.

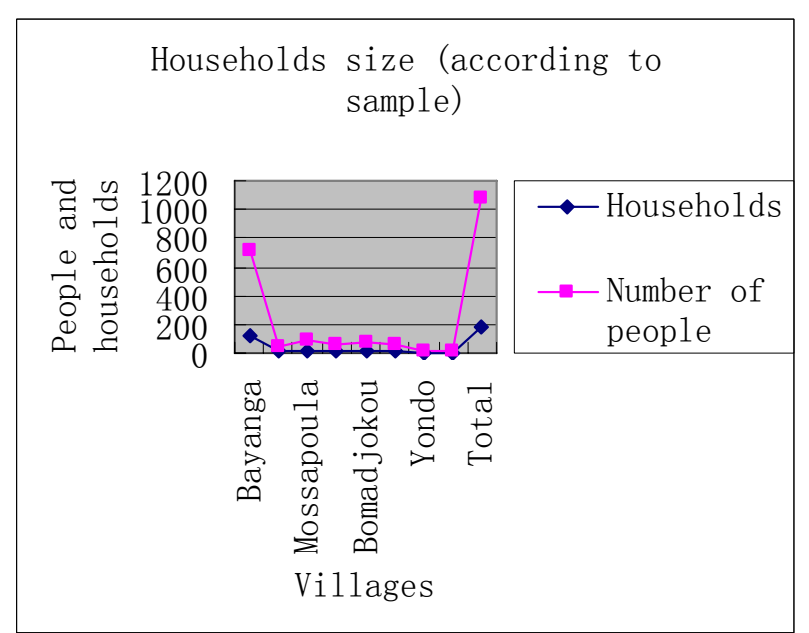

Figure 4. Households size

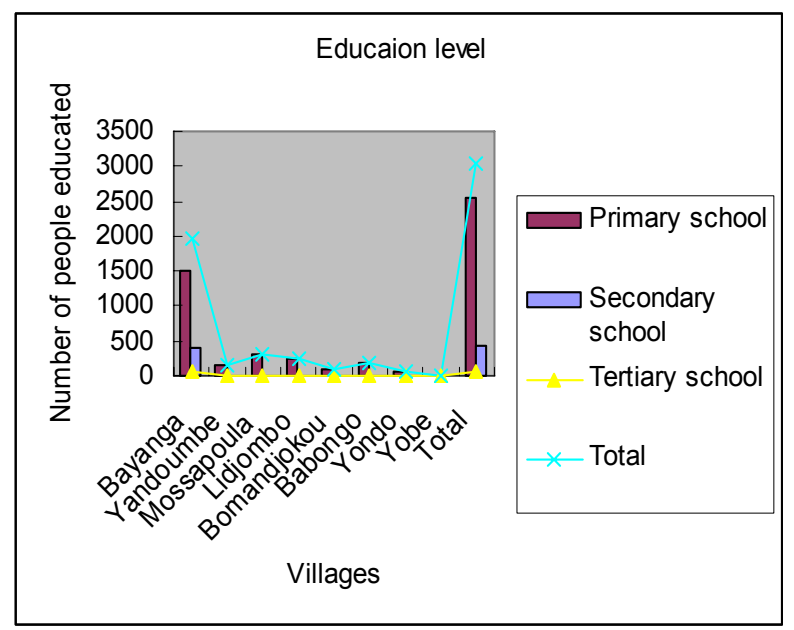

Figure 6 . Results of primary, secondary and tertiary education

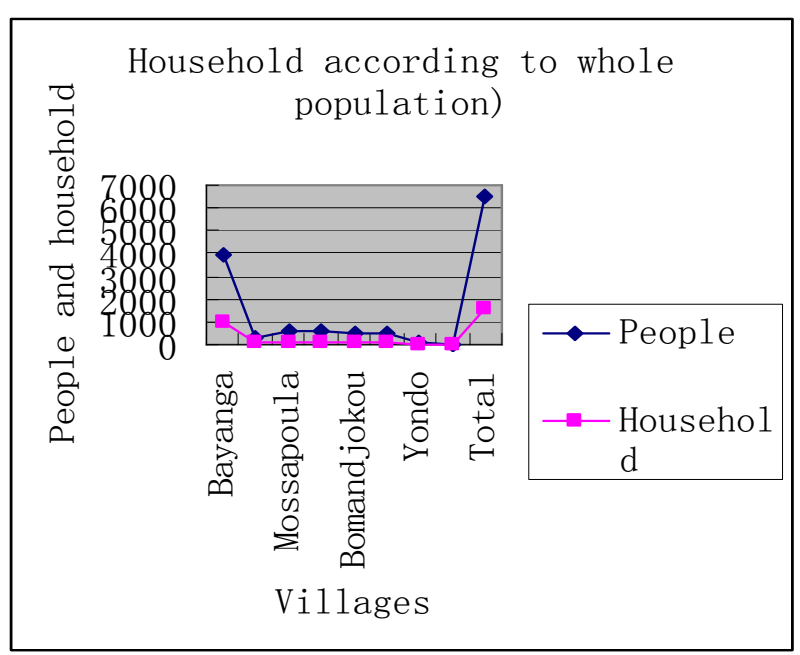

Figure 3. People and households in Dzanga Sangha

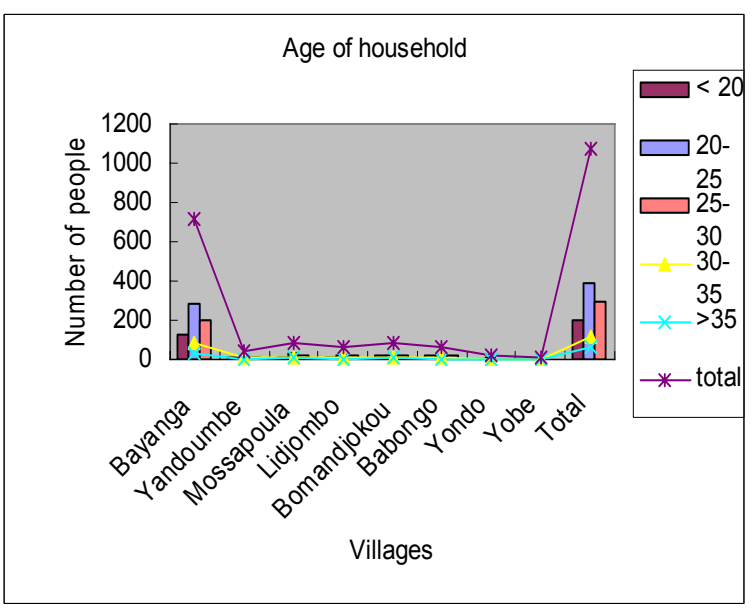

Figure 5. this chart shows that many people in the Special Reserve have 20-25 and 25-30 years olds

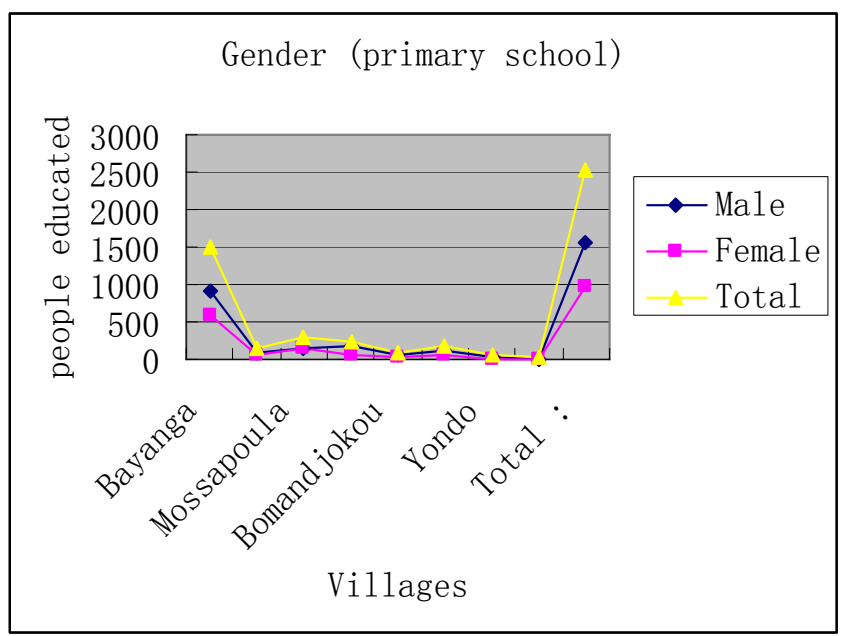

Figure 7. Gender primary School 


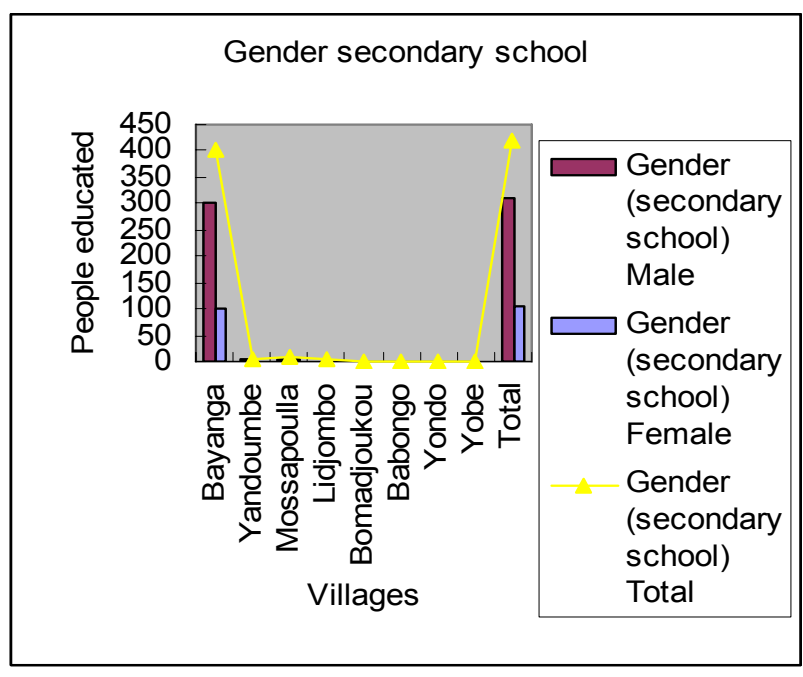

Figure 8. Gender secondary school

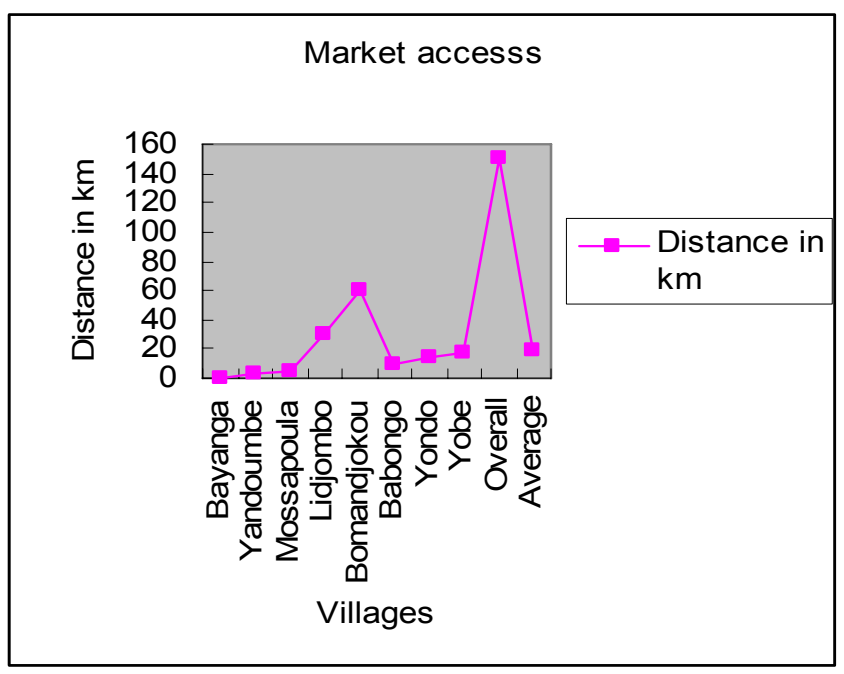

Figure10. This table show distance from each village to market access

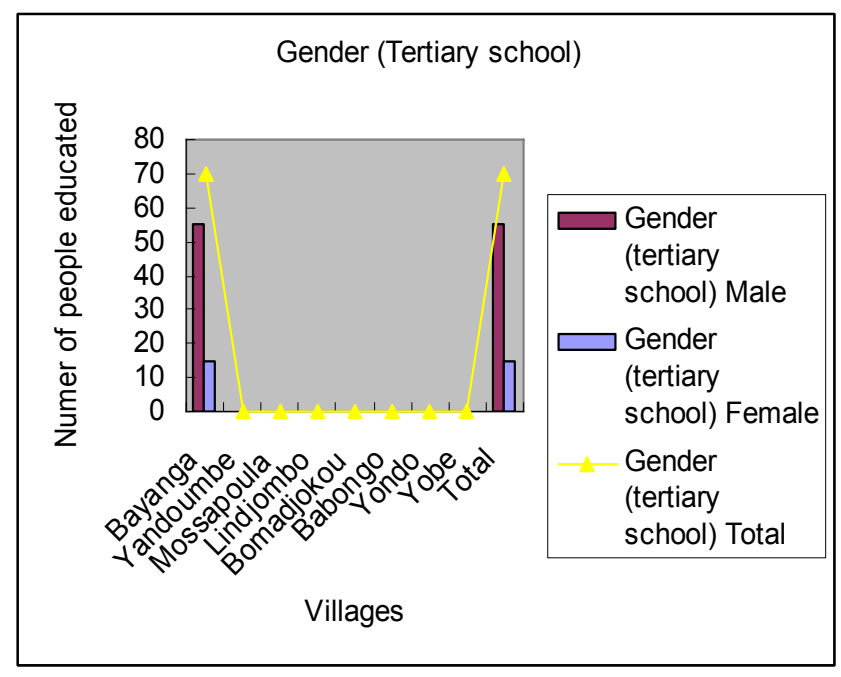

Figure 9. Gender tertiary educations

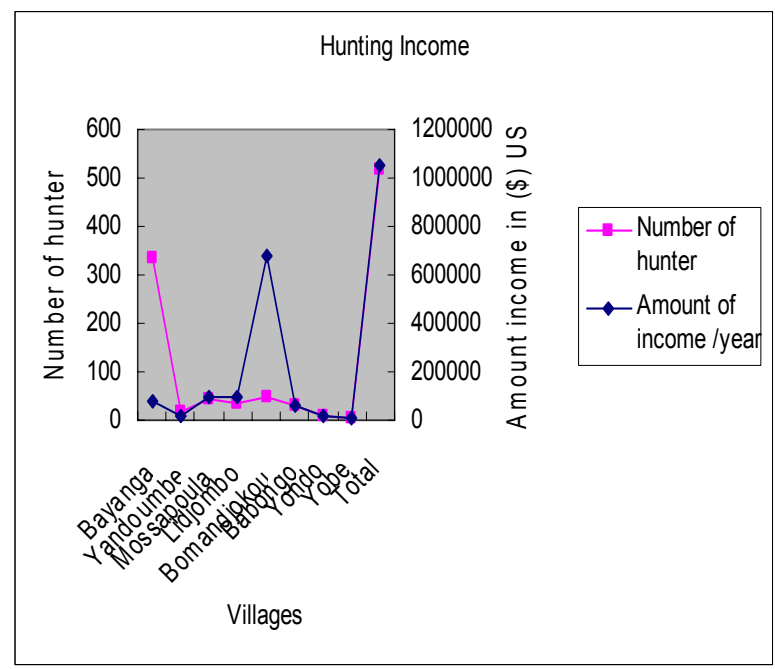

Figure 11a. Variation of hunting income, number of hunter from each village

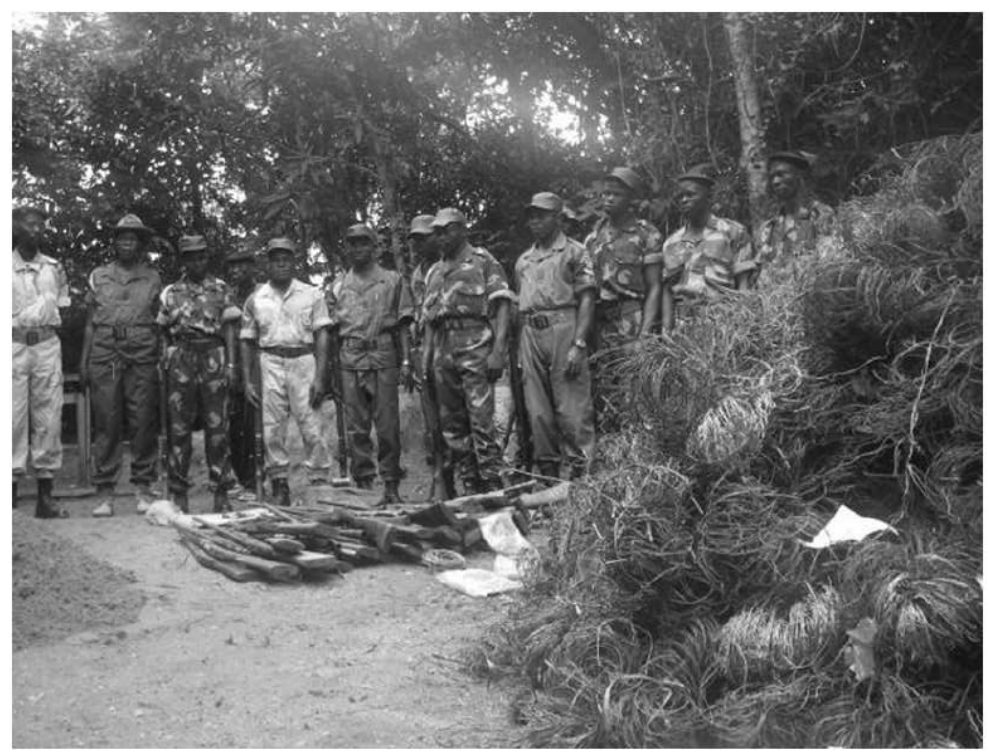

Figure 11b. Forest guards: local fabrication gun, snares cable, confiscated during their patrol 


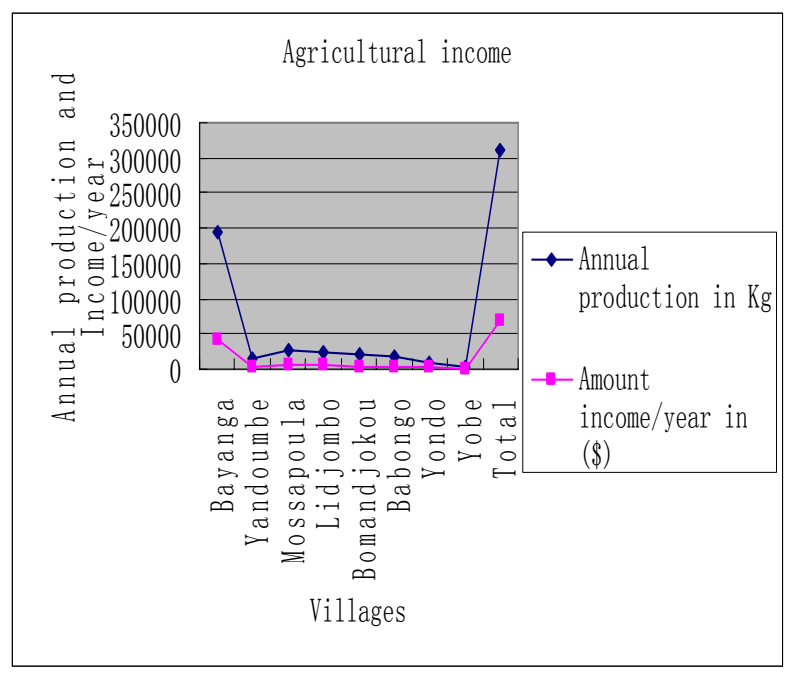

Figure 12. Agricultural income for each village in the Special Reserve

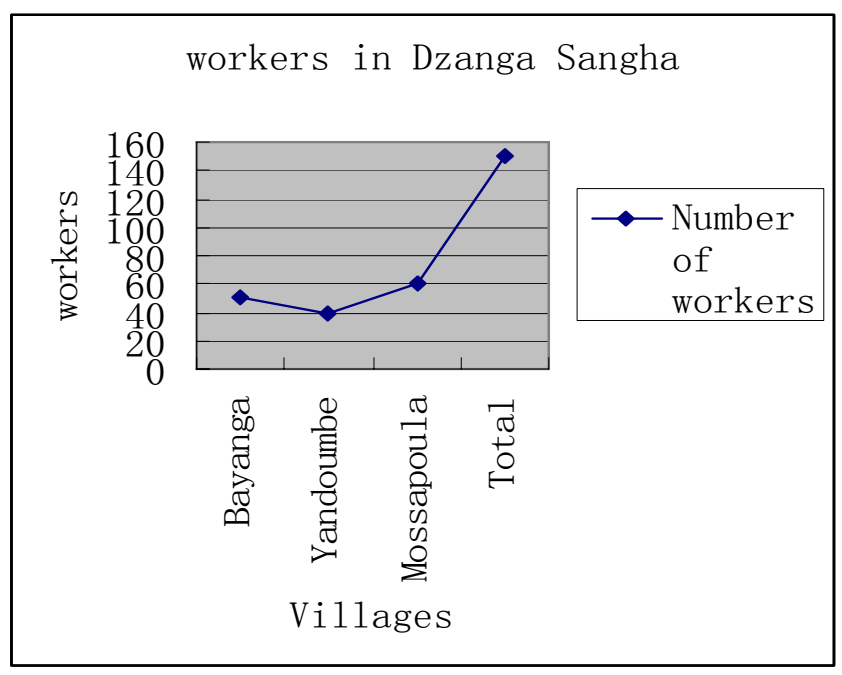

Figure 13. Workers in Dzanga Sangha project with their respective villages 